Article

\title{
Probing Steroidal Substrate Specificity of Cytochrome P450 BM3 Variants
}

\author{
Xing Liu, Zhi-Biao Wang, Ya-Nan Wang and Jian-Qiang Kong * \\ State Key Laboratory of Bioactive Substance and Function of Natural Medicines \& Ministry of Health Key \\ Laboratory of Biosynthesis of Natural Products, Institute of Materia Medica, Chinese Academy of Medical \\ Sciences \& Peking Union Medical College, Beijing 100050, China; seraphlx@imm.ac.cn (X.L.); \\ wangzhibiao@live.cn (Z.-B.W.); wangyanan@imm.ac.cn (Y.-N.W.) \\ * Correspondence: jianqiangk@imm.ac.cn; Tel.: +86-106-316-5169
}

Academic Editor: Marcello Iriti

Received: 27 April 2016; Accepted: 6 June 2016; Published: 11 June 2016

\begin{abstract}
M01A82W, M11A82W and M01A82WS72I are three cytochrome P450 BM3 (CYP102A1) variants. They can catalyze the hydroxylation of testosterone (TES) and norethisterone at different positions, thereby making them promising biocatalysts for steroid hydroxylation. With the aim of obtaining more hydroxylated steroid precursors it is necessary to probe the steroidal substrate diversity of these BM3 variants. Here, three purified BM3 variants were first incubated with eight steroids, including testosterone (TES), methyltestosterone (MT), cholesterol, $\beta$-sitosterol, dehydroepiandrosterone (DHEA), diosgenin, pregnenolone and ergosterol. The results indicated that the two 3-keto- $\Delta^{4}$-steroids TES and MT can be hydroxylated at various positions by the three BM3 mutants, respectively. On the contrary, the three enzymes displayed no any activity toward the remaining six 3-hydroxy- $\Delta^{5}$-steroids. This result indicates that the BM3 mutants prefer 3-keto- $\Delta^{4}$-steroids as hydroxylation substrates. To further verify this notion, five other substrates, including two 3-hydroxy- $\Delta^{5}$-steroids and three 3-keto- $\Delta^{4}$-steroids, were carefully selected to incubate with the three BM3 variants. The results indicated the three 3-keto- $\Delta^{4}$-steroids can be metabolized to form hydroxysteroids by the three BM3 variants. On the other hand, the two 3-hydroxy- $\Delta^{5}$-steroids cannot be hydroxylated at any position by the BM3 mutants. These results further support the above conclusion, therefore demonstrating the 3-keto- $\Delta^{4}$-steroid substrate preference of BM3 mutants, and laying a foundation for microbial production of more hydroxylated steroid intermediates using BM3 variants.
\end{abstract}

Keywords: BM3 variants; substrate specificity; 3-hydroxy- $\Delta^{5}$-steroids; 3-keto- $\Delta^{4}$-steroids; hydroxylation

\section{Introduction}

The hydroxylation of steroids is an important enzymatic reaction in steroid metabolism and the resultant hydroxylated steroids can be used as the key-intermediates for the biosynthesis of steroid drugs with diverse therapeutic purposes [1-5]. Both chemical and biological approaches are thus used for the production of hydroxylated steroids [4-8]. Chemical synthesis suffers from the complexity of hydroxysteroids, as well as the necessity of extreme reaction conditions and the production of toxic by-products $[9,10]$. There are no reports, therefore, concerning the large scale production of hydroxylated steroids by chemical synthesis methods. The biotechnological production of hydroxysteroids by enzyme-catalyzed reactions or whole-cell biotransformation has made great strides over the years. Several isolated P450s and engineered strains containing heterologous P450s have been reported to hydroxylate steroids at various positions $[6,7,11,12]$. Among these biological methods, steroid oxidations catalyzed by engineered P450 BM3 mutants have recently 
gained importance for their potential use to generate rather diverse and unique hydroxylated steroids displaying important pharmacological activities [6-8,11].

Cytochrome P450 BM3, a well-known monooxygenase from Bacillus megaterium, was initially found to catalyze the NADPH-dependent hydroxylation of long-chain fatty acids $[13,14]$. Later, P450 BM3 has been engineered to accommodate a wide range of other substrates including short- and medium-chain fatty acid, alkanes and steroids [15-17]. More recently, engineered P450 BM3 variants have been reported to selectively hydroxylate steroids at various positions $[6-8,11,18]$. The first steroid-hydroxylating BM3 variant was reported in 2006 [8]. In that paper, a triple and two double mutants were shown to form mainly $16 \beta-\mathrm{OH}-\mathrm{TES}$ [8]. Since then, different BM3 variants, like M01A82W, M11A82W and M01A82WS72I, have been described as biocatalysts for steroid hydroxylation with altered regio- and stereoselectivity [6,7,11,18-20]. P450 BM3 variants are thus deemed good biocatalyst candidates for the oxidative hydroxylation of steroids. The aim of previous studies was usually to identify BM3 mutants capable of hydroxylating steroids at different positions. Hence, only a few steroids, like TES [8,20], norethisterone [11,19] and progesterone [20], were used as probes to verify the hydroxylation activity of different BM3 mutants. The limited steroid substrate specificity of these BM3 mutants impedes their widespread application in the hydroxylation of steroidal precursors. It has long been known that drug-metabolising P450s with substrate promiscuity are a key factor in natural-product diversification. Therefore, it is necessary to probe the steroidal substrate diversity of these BM3 variants in order to obtain more novel hydroxylated steroid precursors. Here, the steroidal substrate specificity of three BM3 mutants M01A82W, M11A82W and M01A82WS72I, which were shown previously to hydroxylate TES and norethisterone at various positions, was explored. Specifically, the hydroxylation of eight steroids by three purified BM3 variants was performed first. The results indicated that only 3-keto- $\Delta^{4}$-steroids can be metabolized to hydroxylated metabolites. To verify this conclusion, five other steroids including three 3-keto- $\Delta^{4}$-steroids and two 3-hydroxy- $\Delta^{5}$-steroids were carefully selected and incubated with the aforementioned BM3 mutants. Detailed analysis showed only the three 3-keto- $\Delta^{4}$-steroids could be metabolized into different hydroxylated metabolites, confirming a substrate preference of BM3 mutants for 3-keto- $\Delta^{4}$-steroids. These results broaden the known steroidal substrate promiscuity of BM3 variants, thereby expanding their synthetic utility as biological catalysts.

\section{Results and Discussion}

\subsection{Expression and Purification of BM3 Mutants}

The pET28aM01A82W, pET28aM11A82W and pET28aM01A82WS72I were transformed into the Escherichia coli strain Transetta (DE3) for heterologous expression, respectively.

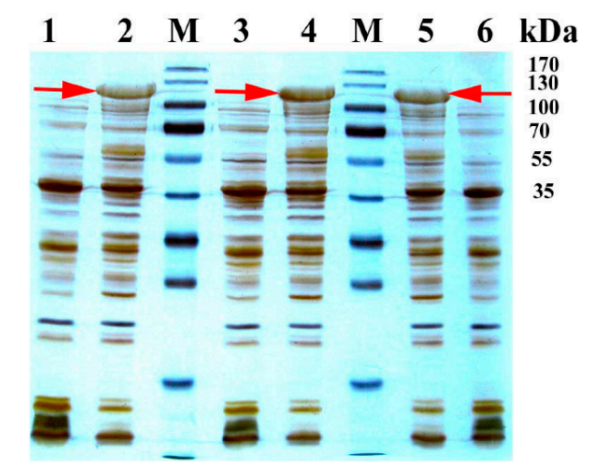

Figure 1. SDS-PAGE analysis of recombinant BM3 mutants. Crude protein extracts from a transformant expressing M01A82W (lane 2), M01A82WS72I (lane 4), M11A82W (lane 5) or empty vector (lanes 1, 3, 6). Lane $\mathrm{M}$ shows the proteins marker with the indicated molecular masses. The arrows indicated the recombinant $\mathrm{BM} 3$ proteins. 
As depicted in Figure 1, an intense band with an apparent molecular mass of 119 kDa was determined by sodium dodecyl sulfate-polyacrylamide gel electrophoresis (SDS-PAGE) detection, suggesting the successful expression of a soluble M01A82W, M11A82W and M01A82WS72I protein. The resulting three soluble proteins were then purified to apparent homogeneity using immobilized metal affinity chromatography (IMAC).

\subsection{Metabolism of TES by CYP102A1 Mutants}

The three BM3 mutants were successfully expressed in E. coli. First of all, we needed to determine whether these three purified BM3 variants possessed in vitro activity. Testosterone (Figure 2) has been shown to be hydroxylated by the three BM3 variants tested [6,7].

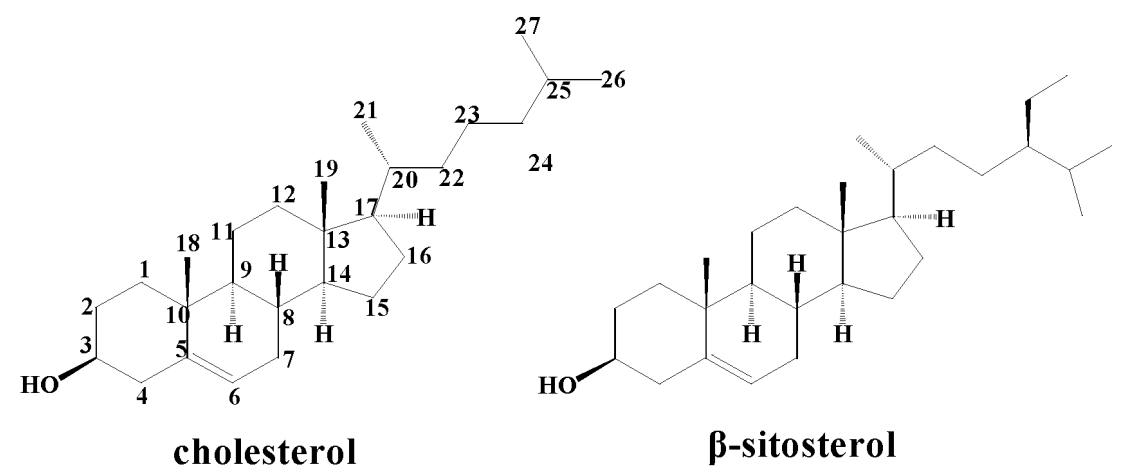<smiles>C[C@]12CC[C@@H]3[C@@H]4CCC(O)CC4=CC[C@H]3[C@@H]1CCC2=O</smiles>

dehyd roepiand rosterone<smiles>CC(=O)C1CC[C@H]2[C@H]3CC=C4C[C@@H](O)CC[C@]4(C)[C@H]3CC[C@]2(C)[C@H]1C(C)=O</smiles><smiles>CCCC(=O)C=C1CCC2C3C(O)CCC2(C)C(O)CCC13C</smiles>

testosterone<smiles>CC1COC2(C1)CC(C)C(C)C1C(CC3(C)C4CC=C5CC(O)CCC5(C)C4CCC13C)O2</smiles>

diosgenin<smiles>CC(C)C(C)/C=C/C(C)[C@H]1CC[C@H]2C3=CC=C4C[C@@H](O)CC[C@]4(C)[C@H]3CC[C@]21C</smiles>

ergosterol<smiles>CC1(O)CCC2C1CCC1(C)C2CCC2=CC(=O)CCC21C</smiles>

methyltestosterone

Figure 2. Chemical structures of the compounds used in this study.

Hence TES was utilized as a probe for the activity characterization of the three BM3 variants in the present investigation. As illustrated in Figure 3, a total of four, five and four new metabolites were 
formed when TES was incubated with M01A82W, M01A82WS72I and M11A82W, respectively, thereby suggesting that the three purified BM3 mutants are active.

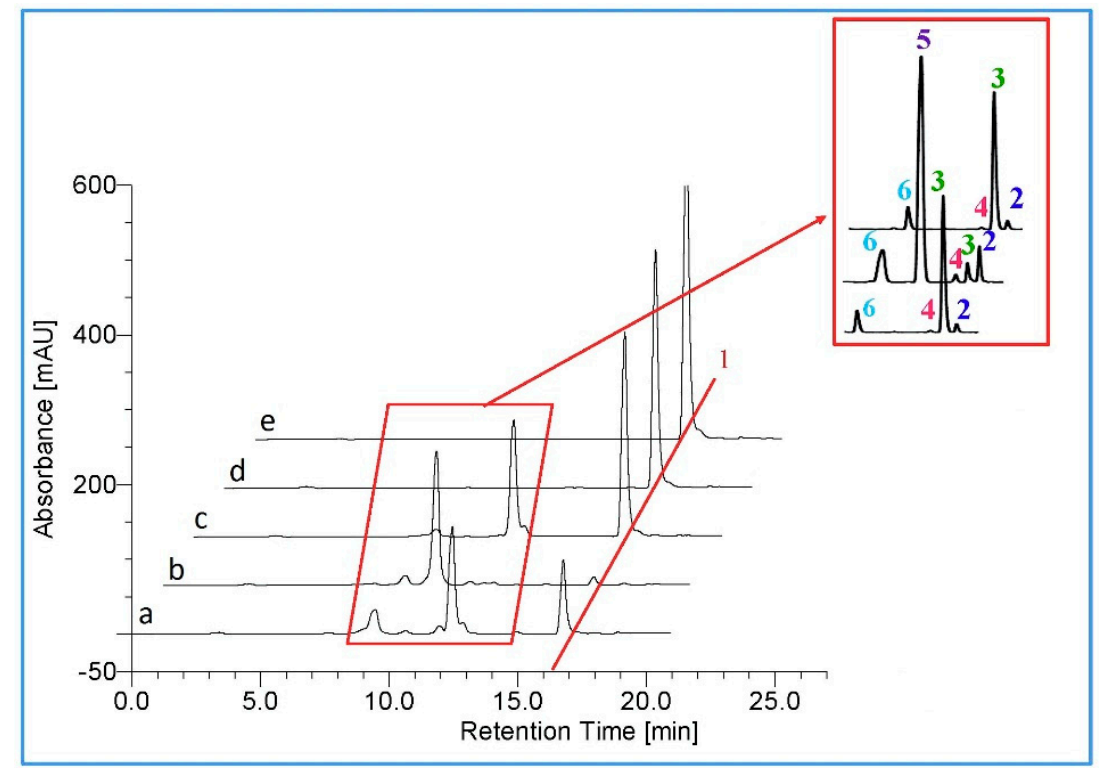

Figure 3. (a) HPLC chromatogram of testosterone; (b-e) testosterone incubation with empty vector, M01A82W, M01A82WS72I and M11A82W, respectively. Peak 1 is the testosterone standard. Peaks 2, 3, 4,5 and 6 indicate the monohydroxy metabolites of testosterone produced by the various BM3 variants.

However, this number of products is inconsistent with previous reports [6,7]. TES was metabolized by M01A82WS72I to five metabolites, one product more than those catalyzed by the same BM3 mutant described by Venkataraman et al. [6]. All five metabolites were identified by LC-MS as monohydroxylated metabolites $(\mathrm{m} / \mathrm{z}$ 305) (Figure S1). Product 5 was the major metabolite. For structure characterization of the major metabolite, a large-scale incubation, which contained $17.5 \mathrm{~mL}$ crude proteins (derived from $1000 \mathrm{~mL}$ cultures), $500 \mu \mathrm{M}$ testosterone, $500 \mu \mathrm{M}$ nicotinamide adenine dinucleotide phosphate, reduced form (NADPH), and a regeneration system $\left(0.3 \mathrm{mM} \mathrm{NADP}^{+}, 0.8 \mathrm{mM}\right.$ glucose 6-phosphate and $0.8 \mathrm{mM} \mathrm{MgCL}_{2}$ and $0.4 \mathrm{U} / \mathrm{mL}$ glucose 6-phosphate dehydrogenase), was performed at $28{ }^{\circ} \mathrm{C}$ for $3 \mathrm{~h}$. The reaction mixture was extracted with chloroform. The chloroform extract was evaporated to dryness and the residues were resolubilized in acetonitrile. The resulting high performance liquid chromatography (HPLC) injection solution was subsequently filtered prior to preparative HPLC. The preparative major metabolite 5 was subjected to $600 \mathrm{MHz}$ NMR analysis and the structure of the major metabolite was assigned as $16 \alpha$-hydroxytestosterone $(16 \alpha-\mathrm{OH}-\mathrm{T})$ based on its ${ }^{1} \mathrm{H}-\mathrm{NMR}$ spectra and previously published data [6]. Details of the ${ }^{1} \mathrm{H}$ spectra are tabulated in Table 1. Previous results indicated that $16 \alpha-\mathrm{OH}-\mathrm{T}$ was eluted between $15 \beta$ - and $16 \beta-\mathrm{OH}-\mathrm{T}$. There was only one metabolite (product 6) that eluted before $16 \alpha-\mathrm{OH}-\mathrm{T}$. Metabolite 6 was therefore presumed to be $15 \beta-\mathrm{OH}-\mathrm{T}$. The result presented by Venkataraman et al showed there were two metabolites, namely $16 \beta$ - and $2 \beta-\mathrm{OH}-\mathrm{T}$, which eluted after $16 \alpha-\mathrm{OH}-\mathrm{T}$. However, in the chromatogram illustrated in Figure 3 , there are three monohydroxylated metabolites $(2,3$ and 4$)$ that eluted after $16 \alpha-\mathrm{OH}-\mathrm{T}$.

To identify the exact structures of these three metabolites, the preparative separation and subsequent NMR analysis of the three metabolites were performed as mentioned above. Metabolite 2 was identified as $2 \beta-\mathrm{OH}-\mathrm{T}$, whereas metabolite 3 was identified as $16 \beta-\mathrm{OH}-\mathrm{T}$ (Table 1 ). Since the fifth metabolite (product 4) was only formed in a tiny amount, no further efforts were made to establish its exact structure. 
Table $1 .{ }^{1} \mathrm{H}$ and ${ }^{13} \mathrm{C}-\mathrm{NMR}$ data for $16 \beta-\mathrm{OH}-\mathrm{T}, 16 \alpha-\mathrm{OH}-\mathrm{T}$ and $2 \beta$-OH-T (600 MHz for ${ }^{1} \mathrm{H}-\mathrm{NMR}$ and $150 \mathrm{MHz}$ for ${ }^{13} \mathrm{C}-\mathrm{NMR}, \mathrm{D}_{2} \mathrm{O}, \delta$ in ppm).

\begin{tabular}{|c|c|c|c|c|c|}
\hline \multirow{2}{*}{ Position } & \multicolumn{2}{|c|}{$16 \beta-\mathrm{OH}-\mathrm{T}$} & \multirow{2}{*}{$\frac{16 \alpha-\mathrm{OH}-\mathrm{T}^{*}}{\delta_{\mathrm{H}}}$} & \multicolumn{2}{|r|}{$2 \beta-\mathrm{OH}-\mathrm{T}$} \\
\hline & $\delta_{C}$ & $\delta_{H}$ & & $\delta_{\mathrm{C}}$ & $\delta_{\mathbf{H}}$ \\
\hline 1 & 35.7 & $\begin{array}{l}1.50-1.42(\mathrm{~m}, 1 \mathrm{H}) \\
1.88-1.84(\mathrm{~m}, 1 \mathrm{H})\end{array}$ & $\begin{array}{l}1.50-1.47(\mathrm{~m}, 1 \mathrm{H}) \\
1.80-1.77(\mathrm{~m}, 1 \mathrm{H})\end{array}$ & 41.3 & $1.63-1.56(\mathrm{~m}, 1 \mathrm{H}) ; 2.05(\mathrm{~m}, 1 \mathrm{H})$ \\
\hline 2 & 34 & $\begin{array}{l}2.06-2.00(\mathrm{~m}, 1 \mathrm{H}) \\
2.34-2.27(\mathrm{~m}, 1 \mathrm{H})\end{array}$ & $\begin{array}{l}2.04-2.00(\mathrm{~m}, 1 \mathrm{H}) \\
2.35-2.29(\mathrm{~m}, 1 \mathrm{H})\end{array}$ & 68.6 & $4.00-3.95(\mathrm{~m}, 1 \mathrm{H})$ \\
\hline 3 & 199.5 & & & 199.4 & \\
\hline 4 & 124 & $5.73(\mathrm{~s}, 1 \mathrm{H})$ & $5.72(\mathrm{~s}, 1 \mathrm{H})$ & 120.3 & $5.63(\mathrm{~s}, 1 \mathrm{H})$ \\
\hline 5 & 170.9 & & & 172 & \\
\hline 6 & 32.7 & $\begin{array}{l}2.28-2.26(\mathrm{~m}, 1 \mathrm{H}) \\
2.37-2.34(\mathrm{~m}, 1 \mathrm{H})\end{array}$ & $\begin{array}{l}2.29-2.25(\mathrm{~m}, 1 \mathrm{H}) \\
2.42-2.37(\mathrm{~m}, 1 \mathrm{H})\end{array}$ & 30.3 & $2.19-2.16(\mathrm{~m}, 1 \mathrm{H}) ; 2.40-2.37(\mathrm{~m}, 1 \mathrm{H})$ \\
\hline 7 & 31.7 & $\begin{array}{l}1.02-0.97(\mathrm{~m}, 1 \mathrm{H}) \\
1.73-1.68(\mathrm{~m}, 1 \mathrm{H})\end{array}$ & $\begin{array}{l}1.00-0.98(\mathrm{~m}, 1 \mathrm{H}) \\
1.73-1.68(\mathrm{~m}, 1 \mathrm{H})\end{array}$ & 32.5 & $0.85(\mathrm{~m}, 1 \mathrm{H}) ; 1.87-1.84(\mathrm{~m}, 1 \mathrm{H})$ \\
\hline 8 & 35 & $1.50-1.42(\mathrm{~m}, 1 \mathrm{H})$ & $1.50-1.47(\mathrm{~m}, 1 \mathrm{H})$ & 34.1 & $1.63-1.56(\mathrm{~m}, 1 \mathrm{H})$ \\
\hline 9 & 54.1 & $0.97-0.93(\mathrm{~m}, 1 \mathrm{H})$ & $0.99-0.96(\mathrm{~m}, 1 \mathrm{H})$ & 51.1 & $1.37-1.34(\mathrm{~m}, 1 \mathrm{H})$ \\
\hline 10 & 42.4 & & & 43.3 & \\
\hline 11 & 20.4 & $\begin{array}{l}1.31-1.27(\mathrm{~m}, 1 \mathrm{H}) \\
1.35-1.31(\mathrm{~m}, 1 \mathrm{H})\end{array}$ & $1.47-1.44(\mathrm{~m}, 2 \mathrm{H})$ & 22.1 & $1.63-1.56(\mathrm{~m}, 1 \mathrm{H}) ; 1.50-1.44(\mathrm{~m}, 1 \mathrm{H})$ \\
\hline 12 & 37 & $\begin{array}{l}1.06-1.03(\mathrm{~m}, 1 \mathrm{H}) \\
1.67-1.63(\mathrm{~m}, 1 \mathrm{H})\end{array}$ & $\begin{array}{l}1.04-1.00(\mathrm{~m}, 1 \mathrm{H}) \\
1.43-1.40(\mathrm{~m}, 1 \mathrm{H})\end{array}$ & 35.6 & $1.03(\mathrm{~m}, 1 \mathrm{H}) ; 1.78-1.72(\mathrm{~m}, 1 \mathrm{H})$ \\
\hline 13 & 38.7 & & & 36.7 & \\
\hline 14 & 47 & $0.81-0.79(\mathrm{~m}, 1 \mathrm{H})$ & $0.81-0.79(\mathrm{~m}, 1 \mathrm{H})$ & 50.1 & $0.85(\mathrm{~m}, 1 \mathrm{H})$ \\
\hline 15 & 35 & $\begin{array}{l}1.15-1.10(\mathrm{~m}, 1 \mathrm{H}) \\
1.93-1.88(\mathrm{~m}, 1 \mathrm{H})\end{array}$ & $\begin{array}{l}1.83-1.81(\mathrm{~m}, 1 \mathrm{H}) \\
1.06-1.04(\mathrm{~m}, 1 \mathrm{H})\end{array}$ & 23.5 & $1.50-1.44(\mathrm{~m}, 1 \mathrm{H}) ; 1.34(\mathrm{~m}, 1 \mathrm{H})$ \\
\hline 16 & 70 & $3.39-3.36(\mathrm{~m}, 1 \mathrm{H})$ & $4.17-4.13(\mathrm{~m}, 1 \mathrm{H})$ & 29.5 & $1.85-1.81(\mathrm{~m}, 1 \mathrm{H}) ; 1.43-1.39(\mathrm{~m}, 1 \mathrm{H})$ \\
\hline 17 & 80.7 & $4.19(\mathrm{~m}, 1 \mathrm{H})$ & $3.50(\mathrm{~d}, J 5.7,1 \mathrm{H})$ & 80.3 & $3.47-3.41(\mathrm{~m}, 1 \mathrm{H})$ \\
\hline 18 & 11.9 & $0.86(\mathrm{~s}, 3 \mathrm{H})$ & $0.84(\mathrm{~s}, 3 \mathrm{H})$ & 11.8 & $0.67(\mathrm{~s}, 3 \mathrm{H})$ \\
\hline 19 & 17.4 & $1.20(\mathrm{~s}, 3 \mathrm{H})$ & $1.18(\mathrm{~s}, 3 \mathrm{H})$ & 22.4 & $1.14(\mathrm{~s}, 3 \mathrm{H})$ \\
\hline
\end{tabular}

${ }^{*}$ No ${ }^{13} \mathrm{C}-\mathrm{NMR}$ analysis of $16 \alpha-\mathrm{OH}-\mathrm{T}$ was performed. 
TES was previously reported to be metabolized by both M01A82W and M11A82W to form three monohydroxylated metabolites, namely $2 \beta-\mathrm{OH}-\mathrm{T}, 15 \beta-\mathrm{OH}-\mathrm{T}$ and $16 \beta-\mathrm{OH}-\mathrm{T}$ [7]. In the present investigation, $2 \beta-\mathrm{OH}-\mathrm{T}$ (product 2), $15 \beta-\mathrm{OH}-\mathrm{T}$ (product 3 ) and $16 \beta-\mathrm{OH}-\mathrm{T}$ (product 6 ) were also identified in the reaction mixture containing M01A82W or M11A82W. Moreover, a fourth trace metabolite 4 was detected in both the reaction mixtures. Although the exact structure of product 4 was not fully characterized due to its trace amounts, the MS data identifies it as a monohydroxylated testosterone derivative.

During the preparation of the hydroxylated metabolites, we used the crude proteins containing BM3 mutants as catalysts. To exclude any interference of E. coli crude proteins, a control strain harboring the empty vector pET-28a (+) was set up. As illustrated in Figure 3, no products were detected in the control E. coli, thereby suggesting the formation of trace product 4 is not caused by the total protein of $E$. coli, thus in this contribution, besides the previously identified metabolites, the three $\mathrm{BM} 3$ variants were found to hydroxylate testosterone at a new position in small amounts.

\subsection{Metabolism of MT by CYP102A1 Mutants}

Having shown that the three purified BM3 mutants possess the in vitro ability to hydroxylate TES at different positions, the three BM3 variants were next used as probes to test different steroidal substrates. Seven steroids, including cholesterol, $\beta$-sitosterol, DHEA, diosgenin, ergosterol, pregnenolone and MT (Figure 2), were incubated with the three P450 BM3 mutants, respectively. The results indicated that new metabolites were formed after incubation of $200 \mu \mathrm{M}$ MT in the presence of the three variants of CYP102A1 (Figure 4).

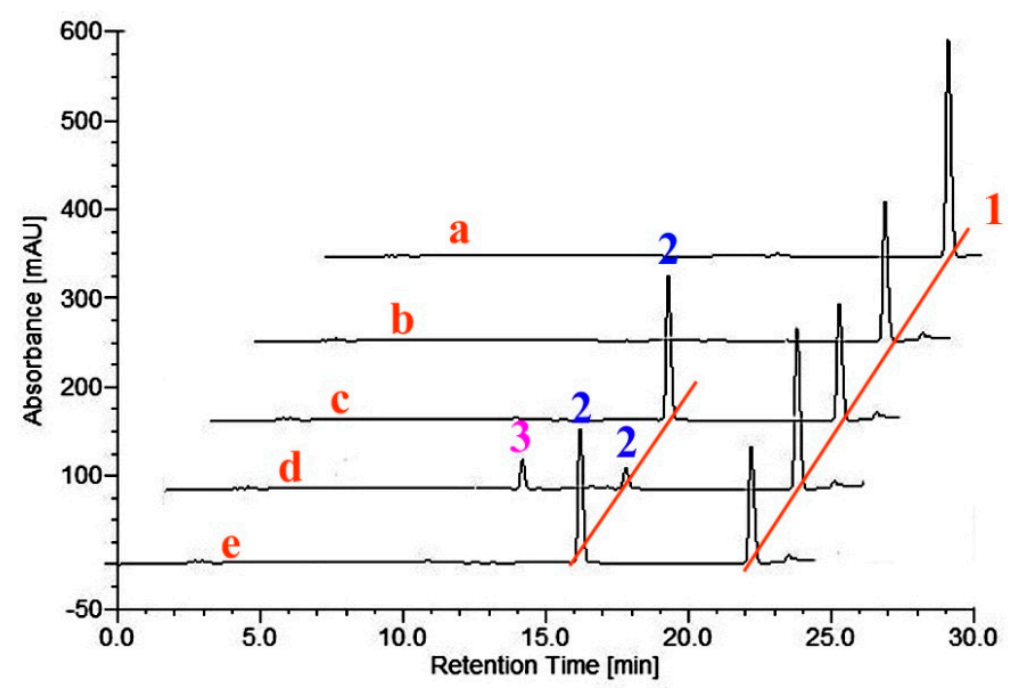

Figure 4. (a) HPLC chromatogram of methyltestosterone; (b-e) methyltestosterone incubations with empty vector, M01A82W, M01A82WS72I and M11A82W, respectively. Peak 1 is the methyl-testosterone standard; peaks 2 and 3 indicate the monohydroxy metabolites of methyltestosterone.

As illustrated in the chromatogram obtained after incubation of BM3 mutant M01A82W with MT, one major metabolite was produced (Figure 4). The mass spectrum of this metabolite showed a $[\mathrm{M}+\mathrm{H}]^{+}$peak at a $m / z$ value of 319.29 (Figure S2), consistent with the introduction of a hydroxyl group into MT. Its structure was determined on the basis of a combination of ${ }^{1} \mathrm{H}-\mathrm{NMR},{ }^{13} \mathrm{C}-\mathrm{NMR}$, $\mathrm{HMQC}, \mathrm{HMBC}$ and CD assays. Detailed ${ }^{1} \mathrm{H}-\mathrm{NMR}$ and ${ }^{13} \mathrm{C}-\mathrm{NMR}$ data are given in Table 2. As shown in the HMBC, there is only one oxygenated methylene signal $(\delta \mathrm{H} 3.63, \mathrm{dd})$, which has long-range correlation both to $20-\mathrm{CH} 3$ and $14-\mathrm{C}$, so the newly hydroxylated methylene is determined to be C-16. The $\mathrm{OH}$ group was determined to be in a $\beta$-orientation from the $\mathrm{CD}$ experiment. After the addition of 
$\mathrm{Mo}_{2}(\mathrm{OAc})_{4}$, a significant positive Cotton effect was observed at $310 \mathrm{~nm}$ (Figure 5), thereby assigning this metabolite as $16 \beta-\mathrm{OH}-\mathrm{MT}$ according to the literature analysis [21,22].
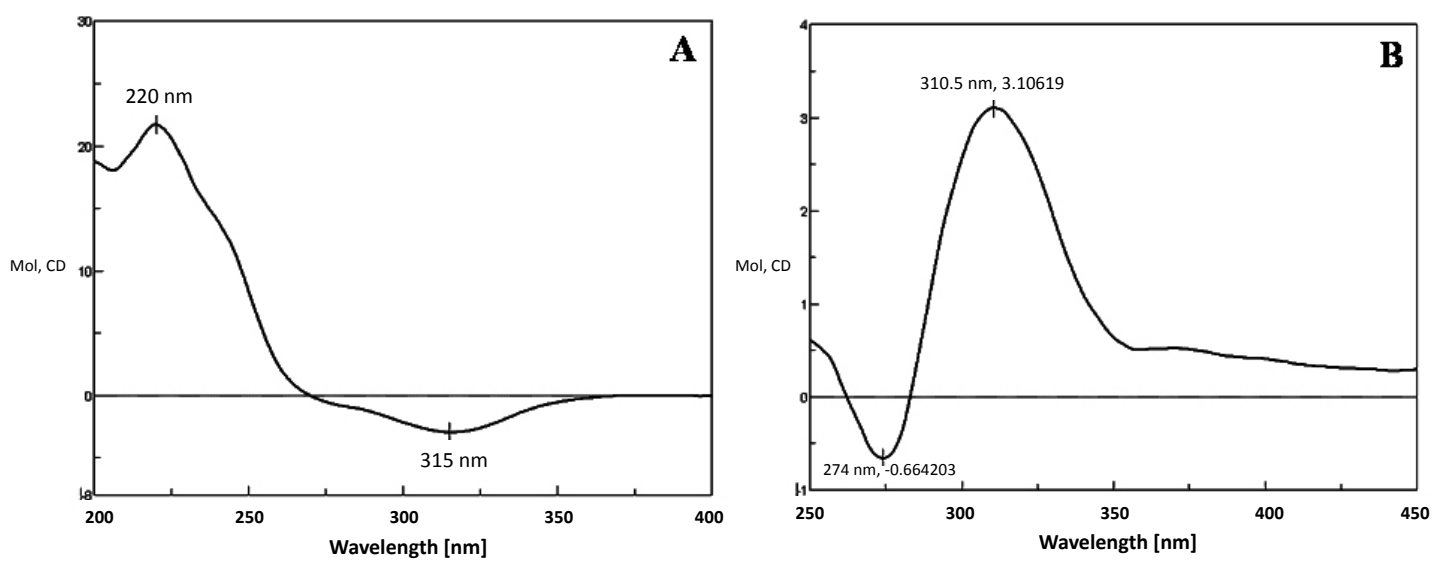

Figure 5. CD spectrum of $16 \beta-\mathrm{OH}-\mathrm{MT}$ without $\mathrm{Mo}_{2}(\mathrm{OAc})_{4}(\mathrm{~A})$ or mixed with $\mathrm{Mo}_{2}(\mathrm{OAc})_{4}(\mathbf{B})$.

M1182W also converted MT to form mainly 16ß-OH-MT (Figure 4). However, M01A82WS72I can metabolize MT to form several new metabolites (Figure 4). Besides the two major metabolites (peaks 2 and 3), there were several metabolites formed in trace amounts that eluted between products 2 and 3 (Figure 4). A HPLC-NMR coupling technology was therefore applied, allowing rapid and detailed structural characterization of the reaction mixture catalyzed by M01A82WS72I. A large-scale incubation $(25 \mathrm{~mL})$ of M01A82WS72I with MT was performed. The resulting reaction mixture was subsequently injected to the HPLC-NMR system for analysis. As illustrated in Figure 6, four new metabolites with retention times $\left(R_{\mathrm{t}}\right)$ of $10.46(\mathrm{~B}), 17.43(\mathrm{C}), 18.90(\mathrm{D})$ and $20.25(\mathrm{E})$ min were obtained after incubation of M01A82WS72I with MT. Figure S3 shows the ESI mass spectrum of the four MT metabolites which generated abundant $[\mathrm{M}+\mathrm{H}]^{+}$ions at a $\mathrm{m} / z$ value of 319 . This pseudomolecular ion was in accordance with the hypothesis of an hydroxylated metabolite of MT [23]. The metabolites eluted at 10.46, 18.90 and 20.25 min were assigned to $16 \alpha-\mathrm{OH}-\mathrm{MT}, 16 \beta-\mathrm{OH}-\mathrm{MT}$ and $2 \beta-\mathrm{OH}-\mathrm{MT}$ based on the NMR spectra and ${ }^{1} \mathrm{H}$ and ${ }^{13} \mathrm{C}$ chemical shifts. The assignment of $16 \beta-\mathrm{OH}-\mathrm{MT}$ is the same as described above. The structural identification of $2 \beta-\mathrm{OH}-\mathrm{MT}$ and $16 \alpha-\mathrm{OH}-\mathrm{MT}$ was described as follows (Table 2):

$16 \alpha-\mathrm{OH}-\mathrm{MT}$ : in the HMBC, there is only one oxygenated methylene signal $\left(\delta_{\mathrm{H}} 4.18\right.$, dd), which has long-range correlations to $20-\mathrm{CH} 3,13-\mathrm{C}$ and $14-\mathrm{C}$, so the newly hydroxylated methylene is determined to be $\mathrm{C}-16$. The oxygenated methane signal $\left(\delta_{\mathrm{H}} 4.18\right)$ is at lower field than in $16 \beta-\mathrm{OH}-\mathrm{MT}\left(\delta_{\mathrm{H}} 3.63\right)$, indicating it is sterically affected by $17-\mathrm{CH} 3$, which is an $\alpha$-orientation. Besides, its HPLC retention time is shorter than that $16 \beta-\mathrm{OH}-\mathrm{MT}$, which together determined the $16-\mathrm{OH}$ to be in the $\alpha$-orientation (Table 2).

2ß-OH-MT: the final quantity obtained was not far from the detection limit of the ${ }^{13} \mathrm{C}-\mathrm{NMR}$ instrument used. The ${ }^{1} \mathrm{H}-\mathrm{NMR}$ spectrum was recorded to demonstrate the purity of the product and to confirm its structure. In the HMBC, 4-H $\left(\delta_{\mathrm{H}} 5.68\right)$ is long-ranged correlated to C-2, C-6, and C-10. In the 3 signal of the 3 -carbonyl, the $\delta_{C}$ of $C-2$ should be the largest $\left(\delta_{C} 69.0\right)$. In the HMQC, it is directly correlated to the only one oxygenated methylene signal $(\delta \mathrm{H} 4.15, \mathrm{dd})$. All these clues suggest the hydroxyl group is attached to C-2.The narrow-wide doublet-doublet shape of $\mathrm{H}-2$ indicated that this proton was axial. In other words, the orientation of the hydroxyl was on the $\beta$-face [24].

Details of the ${ }^{1} \mathrm{H}$ - and ${ }^{13} \mathrm{C}-\mathrm{NMR}$ spectra of $2 \beta-\mathrm{OH}-\mathrm{MT}$ and $16 \alpha-\mathrm{OH}-\mathrm{MT}$ are also tabulated in Table 2.

The metabolite $C$ eluted at 17.43 min has not been well-characterized due to the trace amount available. The three BM3 mutants did not metabolize any of the other six steroids tested. 
Table 2. NMR data for $16 \alpha-\mathrm{OH}-\mathrm{MT}, 16 \beta-\mathrm{OH}-\mathrm{MT}$ and $2 \beta-\mathrm{OH}-\mathrm{MT}$ (600 MHz for ${ }^{1} \mathrm{H}-\mathrm{NMR}$ and $150 \mathrm{MHz}$ for ${ }^{13} \mathrm{C}-\mathrm{NMR}, \mathrm{D}_{2} \mathrm{O}, \delta$ in ppm) obtained via HPLC-NMR.

\begin{tabular}{|c|c|c|c|c|c|c|c|c|c|}
\hline \multirow{2}{*}{ Position } & \multicolumn{3}{|c|}{$16 \alpha-\mathrm{OH}-\mathrm{MT}$} & \multicolumn{3}{|c|}{$16 \beta-\mathrm{OH}-\mathrm{MT}$} & \multicolumn{3}{|c|}{$2 \beta-\mathrm{OH}-\mathrm{MT}$} \\
\hline & $\delta_{\mathrm{C}}$ & $\delta_{H}$ & НMBC & $\delta_{\mathrm{C}}$ & $\delta_{\mathrm{H}}$ & НMBC & $\delta_{\mathrm{C}}$ & $\delta_{\mathrm{H}}$ & НМВС \\
\hline 1 & 35.8 & $1.87, \mathrm{~m}$ & $\mathrm{C} 2, \mathrm{C} 3, \mathrm{C} 10, \mathrm{C} 19$ & 36.8 & $2.16, \mathrm{~m}$ & C2, C3 & 41.6 & $1.61-1.68, \mathrm{~m}$ & $\mathrm{C} 2, \mathrm{C} 9, \mathrm{C} 10, \mathrm{C} 19$ \\
\hline 2 & 33.2 & $2.25, \mathrm{~m} ; 2.42, \mathrm{~m}$ & $\mathrm{C} 1, \mathrm{C} 3, \mathrm{C} 4, \mathrm{C} 10$ & 33.9 & $2.25, \mathrm{~m} ; 2.43, \mathrm{~m}$ & $\mathrm{C} 1, \mathrm{C} 3, \mathrm{C} 4$ & 69.8 & $4.15-4.18, \mathrm{~m}$ & $\mathrm{C} 1, \mathrm{C} 3$ \\
\hline 3 & 200.9 & & & 202.4 & & & 201.6 & & \\
\hline 5 & 173.7 & & & 175.1 & & & 174.3 & & \\
\hline 6 & 33.2 & $2.28, \mathrm{~m} ; 2.46, \mathrm{~m}$ & $\mathrm{C} 4, \mathrm{C} 5, \mathrm{C} 7$ & 34.7 & $2.29, \mathrm{~m} ; 2.47, \mathrm{~m}$ & $\mathrm{C} 4, \mathrm{C} 5, \mathrm{C} 7$ & 32.7 & $2.39-2.45, \mathrm{~m} ; 2.51-2.59, \mathrm{~m}$ & $\mathrm{C} 5, \mathrm{C} 7, \mathrm{C} 10$ \\
\hline 7 & 31.4 & $1.38, \mathrm{~m} ; 1.81, \mathrm{~m}$ & $\mathrm{C} 6, \mathrm{C} 8, \mathrm{C} 9$ & 33.1 & $1.03, \mathrm{~m} ; 1.87, \mathrm{~m}$ & $\mathrm{C} 6, \mathrm{C} 8, \mathrm{C} 9$ & 33.9 & $1,31, \mathrm{~m}$ & C5, C9 \\
\hline 8 & 35.8 & $1.60, \mathrm{~m}$ & $\mathrm{C} 6, \mathrm{C} 8, \mathrm{C} 9$ & 37.2 & $1.69, \mathrm{~m}$ & C7, C9 & 35.7 & $1.61-1.68, \mathrm{~m}$ & $\mathrm{C} 9, \mathrm{C} 10, \mathrm{C} 14, \mathrm{C} 15$ \\
\hline 9 & 35.8 & $0.93, \mathrm{~m}$ & $\mathrm{C} 8, \mathrm{C} 10, \mathrm{C} 11, \mathrm{C} 12, \mathrm{C} 19$ & 55.4 & $0.91, \mathrm{~m}$ & $\mathrm{C} 8, \mathrm{C} 10, \mathrm{C} 11, \mathrm{C} 19$ & 51.5 & $0.93, \mathrm{~m}$ & $\mathrm{C} 8, \mathrm{C} 10$ \\
\hline 10 & 38.6 & & & 37.2 & & & 42.4 & & \\
\hline 12 & 31.5 & $1.00, \mathrm{~m} ; 1.67, \mathrm{~m}$ & $\mathrm{C} 9, \mathrm{C} 18$ & 33.5 & $0.94, \mathrm{~m} ; 1.60, \mathrm{~m}$ & $\mathrm{C} 9, \mathrm{C} 13, \mathrm{C} 18$ & 37.8 & $1.26-1.28, \mathrm{~m}$ & C18 \\
\hline 13 & 45.8 & & & 46.0 & & Clo, & 47.2 & $1.20-1.20,110$ & - 10 \\
\hline 14 & 47.9 & $1.41, \mathrm{~m}$ & $\mathrm{C} 13, \mathrm{C} 15, \mathrm{C} 16, \mathrm{C} 18$ & 47.9 & $1.31, \mathrm{~m}$ & $\mathrm{C} 13, \mathrm{C} 15, \mathrm{C} 16, \mathrm{C} 18$ & 49.9 & $0.95-1.03, \mathrm{~m}$ & $\mathrm{C} 8, \mathrm{C} 9, \mathrm{C} 15$ \\
\hline 15 & 32.4 & $1.35, \mathrm{~m} ; 2.06, \mathrm{~m}$ & $\mathrm{C} 13, \mathrm{C} 14, \mathrm{C} 16$ & 35.8 & $0.99, \mathrm{~m} ; 2.06 \mathrm{~m}$ & $\mathrm{C} 13, \mathrm{C} 14, \mathrm{C} 16$ & 24.2 & $1.28-1.30, \mathrm{~m} ; 1.51-1.56, \mathrm{~m}$ & C14, C16 \\
\hline 16 & 79.1 & $4.15, \mathrm{~m}$ & $\mathrm{C} 14, \mathrm{C} 15, \mathrm{C} 17$ & 78.3 & $3.58, \mathrm{~m}$ & $\mathrm{C} 15, \mathrm{C} 17, \mathrm{C} 20$ & 26.1 & $1.80-188, \mathrm{~m}$ & C 15 \\
\hline 17 & 83.4 & & & 79.8 & & & 82.0 & & \\
\hline 18 & 13.4 & $0.89, \mathrm{~s}$ & $\mathrm{C} 12, \mathrm{C} 13, \mathrm{C} 17$ & 14.2 & $0.87, \mathrm{~s}$ & $\mathrm{C} 12, \mathrm{C} 13, \mathrm{C} 17$ & 14.7 & $0.87, \mathrm{~s}$ & $\mathrm{C} 12, \mathrm{C} 13, \mathrm{C} 17$ \\
\hline 19 & 16.2 & $1.21, \mathrm{~s}$ & $\mathrm{C} 1, \mathrm{C} 9$ & 17.7 & $1.22, \mathrm{~s}$ & C9, C10 & 23.0 & $1.21, \mathrm{~s}$ & $\mathrm{C} 13, \mathrm{C} 16, \mathrm{C} 17$ \\
\hline 20 & 16.7 & $1.11, \mathrm{~s}$ & $\mathrm{C} 13, \mathrm{C} 16, \mathrm{C} 17$ & 24.2 & $1.07, \mathrm{~s}$ & $\mathrm{C} 13, \mathrm{C} 16, \mathrm{C} 17$ & 23.5 & $1.16, \mathrm{~s}$ & $\mathrm{C} 5, \mathrm{C} 9, \mathrm{C} 10$ \\
\hline
\end{tabular}




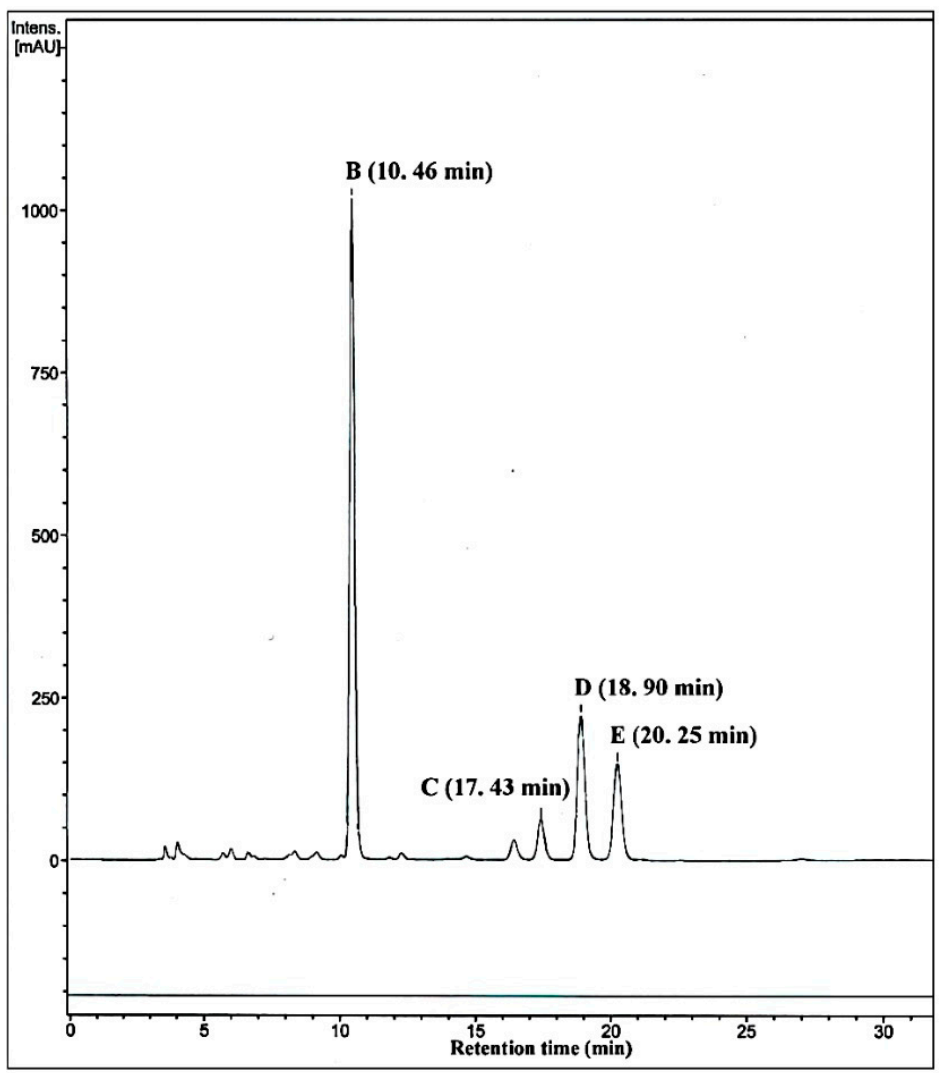

Figure 6. HPLC profile of a large scale incubation of methyltestosterone with M01A82WS72I. The four metabolites eluted at 10.46 (B), 17.43 (C), 18.90 (D) and 20.25 (E) min, respectively.

\subsection{Metabolism of 3-keto-- $\Delta^{4}$-steroids by CYP102A1 Mutants}

Structural analysis reveals that TES and MT are two 3-keto- $\Delta^{4}$-steroids, whereas the other six steroids not hydroxylated by BM3 variants are all 3-hydroxy- $\Delta^{5}$-steroids. Hence, we presumed that the three BM3 mutants preferred 3-keto- $\Delta^{4}$-steroids as substrates. To verify the hypothesis, five steroids, including two 3-hydroxy- $\Delta^{5}$-steroids and three 3-keto- $\Delta^{4}$-steroids, were further carefully selected to incubate with the three BM3 mutants (Figure 7). The two 3-hydroxy- $\Delta^{5}$-steroids include $17 \alpha$-hydropregnenolone and androstenediol, while the other three 3-keto- $\Delta^{4}$-steroids are androstenedione, progesterone and $17 \alpha$-hydroprogesterone (Figure 7). The five compounds, together with the aforementioned three steroids DHEA, pregnenolone and TES, can form four pairs of structurally similar compounds, namely DHEA and androstenedione, pregnenolone and progesterone, $17 \alpha$-hydropregnenolone and $17 \alpha$-hydroprogesterone, as well as androstenediol and TES (Figure 7).

Actually, the four 3-hydroxy- $\Delta^{5}$-steroids are substrates of the respective $\Delta^{4}$-3-keto configuration. The biosynthesis of DHEA from androstenedione, pregnenolone from progesterone, $17 \alpha$-hydropregnenolone from $17 \alpha$-hydroprogesterone, and androstenediol from TES occur under the action of $3 \beta$-hydroxysteroid dehydrogenase $/ \Delta^{5-4}$ isomerase (3ß-HSD, EC 1.1.1.145) (Figure 7). These structurally similar compounds were therefore selected to incubate with the three purified BM3 mutant proteins. HPLC profiles showed the BM3 mutants can metabolize the four 3-keto- $\Delta^{4}$-steroids to form various metabolites (Figures 3, 4, 6 and 8-10). However, there are no new metabolites after incubation of the 3-hydroxy- $\Delta^{5}$-steroids with the three purified enzymes (Figures S5, S7, S9 and S10).

As illustrated in Figure 8, all three BM3 mutants M01A82W, M01A82WS72I and M11A82W can convert progesterone to form three new metabolites $(2,3$ and 4$)$. These new metabolites were identified by MS as monohydroxylated products $(m / z 331$, Figure S4). However, the further structural characterizations of these compounds were not performed due to their trace amount. On the other 
hand, when pregnenolone, a $\Delta^{5}$-3-hydroxy configuration of progesterone, was added into reaction systems containing varied BM3 variants, no new products were detected (Figure S5).

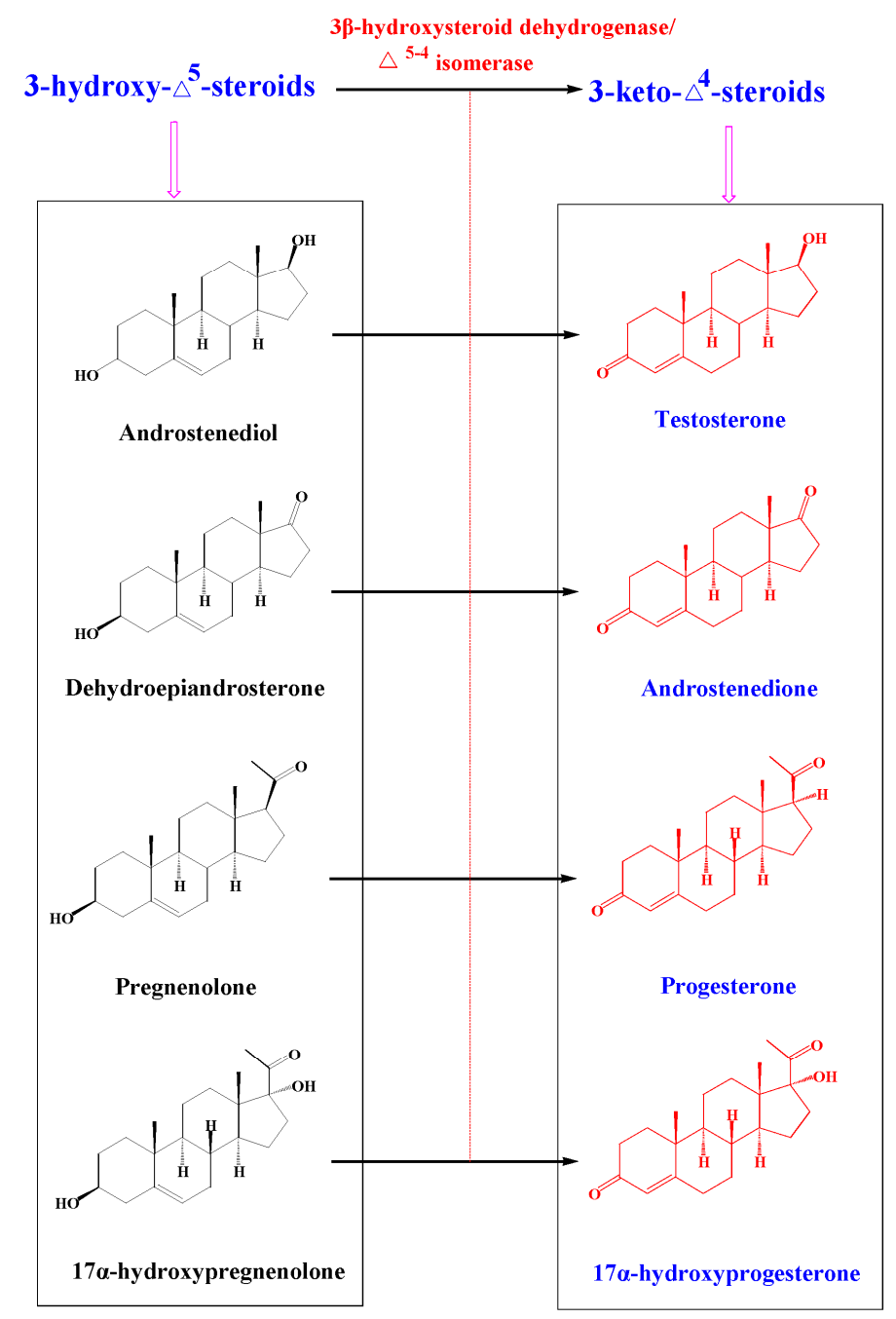

Figure 7. 3-keto- $\Delta^{4}$-steroids and 3-hydroxy- $\Delta^{5}$-steroids used in this study.

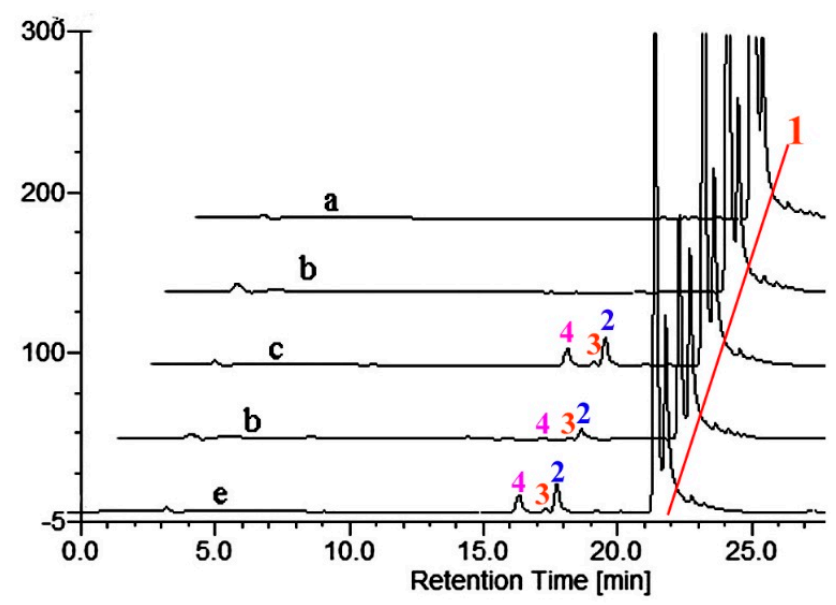

Figure 8. (a) HPLC chromatogram of progesterone; (b)-(e) progesterone incubations with empty vector, M01A82W, M01A82WS72I and M11A82W, respectively. Peak 1 is a progesterone standard; peaks 2, 3 and 4 are three monohydroxylated metabolites of progesterone. 
$17 \alpha$-Hydroxyprogesterone is also a 3-keto- $\Delta^{4}$-steroid. As shown in Figure 9, all the three BM3 enzymes can metabolize $17 \alpha$-hydroxyprogesterone to form two monohydroxylated metabolites with an $m / z$ value of 347 (Figure S6). The concentrations of the two metabolites are too low to perform structural analyses. However, when $17 \alpha$-hydroxypregnenolone, a substrate of $17 \alpha$-hydroxyprogesterone, was incubated with the three BM3 proteins, no new metabolites were appeared in the HPLC profiles (Figure S7).

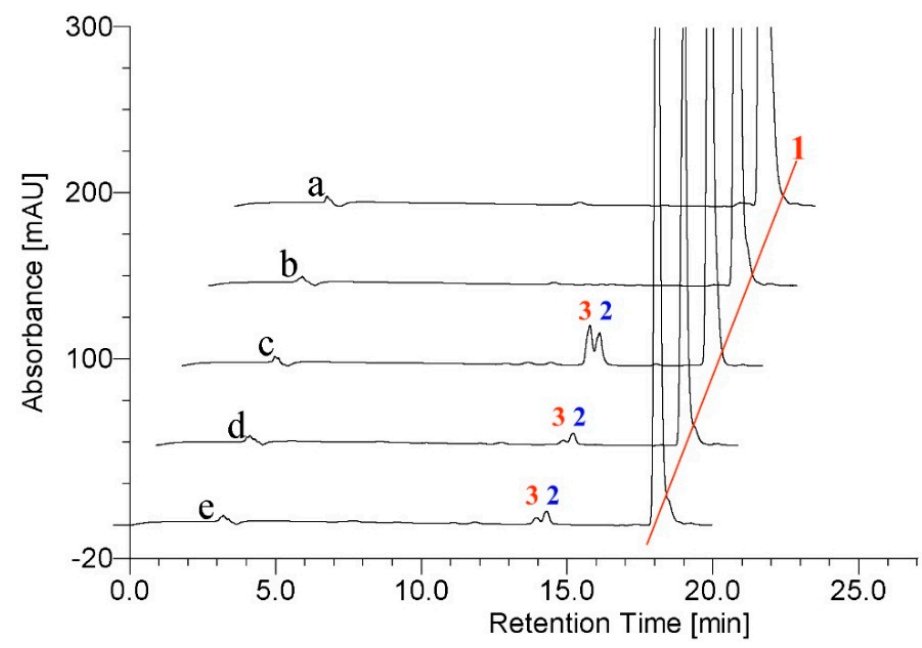

Figure 9. (a) HPLC profile of $17 \alpha$-hydroxyprogesterone; (b-e) $17 \alpha$-hydroxyprogesterone incubations with empty vector. M01A82W. M01A82WS72I and M11A82W, respectively. Peak 1 shows a $17 \alpha$-hydroxyprogesterone standard; peaks 2 and 3 show the two monohydroxylated metabolites of $17 \alpha$-hydroxyprogesterone.

Androstenedione and DHEA are structurally similar compounds. When the two steroids reacted with the three BM3 enzymes, two opposite results were not unexpected. Specifically, androstenedione can be hydroxylated by the three BM3 proteins at varied positions, which can be verified by the corresponding HPLC profile (Figure 10) and ESI-MS results (Figure S8). On the contrary, DHEA has no reactivity with any of the three BM3 variants (Figure S9). As indicated in Figure 10, M01A82W can hydroxylate androstenedione at one position. The sole metabolite was subsequently assigned to be $1 \alpha$-hydroxyandrostenedione based on the combination of LC-MS and NMR analyses. The NMR data details are summarized in Table 3. M11A82W can add a hydroxyl group to androstenedione at the same position. Besides hydroxylating at the 1ß position, M01A82WS72I is able to hydroxylate androstenedione at two other positions. The exact structures of two monohydroxylated metabolites had never been well-characterized due to their trace amount.

Table 3. NMR data for $1 \alpha-\mathrm{OH}$-androstenedione $\left(600 \mathrm{MHz}\right.$ for ${ }^{1} \mathrm{H}-\mathrm{NMR}$ and $150 \mathrm{MHz}$ for ${ }^{13} \mathrm{C}-\mathrm{NMR}$, $\mathrm{DMF}, J$ in $\mathrm{Hz}, \delta$ in ppm).

\begin{tabular}{ccc}
\hline \multirow{2}{*}{ Position } & \multicolumn{2}{c}{ 1 $\boldsymbol{\alpha}$-OH-Androstenedione } \\
\cline { 2 - 3 } & $\boldsymbol{\delta}_{\mathrm{C}}$ & $\boldsymbol{\delta}_{\mathrm{H}}$ \\
\hline 1 & 74.77 & $3.81(\mathrm{t}, J=8.6 \mathrm{~Hz}, 1 \mathrm{H})$ \\
2 & 35.73 & $2.40-2.36(\mathrm{~m}, 1 \mathrm{H}) 2.42(\mathrm{dd}, J=14.0 \mathrm{~Hz}, 5.0,1 \mathrm{H})$ \\
3 & 198.22 & $5.57(\mathrm{~s}, 1 \mathrm{H})$ \\
4 & 123.55 & \\
5 & 170.74 & $2.26-2.19(\mathrm{~m}, 2 \mathrm{H})$ \\
6 & 32.34 & $0.94-0.88(\mathrm{~m}, 1 \mathrm{H}) 1.88-1.85(\mathrm{~m}, 1 \mathrm{H})$ \\
7 & 31.59 & $1.58-1.53(\mathrm{~m}, 1 \mathrm{H})$ \\
8 & 33.96 & $1.68-1.63(\mathrm{~m}, 1 \mathrm{H})$ \\
9 & 46.63 & \\
\hline
\end{tabular}


Table 3. Cont.

\begin{tabular}{ccc}
\hline \multirow{2}{*}{ Position } & \multicolumn{2}{c}{ 1 $\boldsymbol{\alpha}$-OH-Androstenedione } \\
\cline { 2 - 3 } & $\delta_{\mathrm{C}}$ & $\delta_{\mathbf{H}}$ \\
\hline 10 & 38.92 & $1.43-1.34(\mathrm{~m}, 1 \mathrm{H}) 1.58-1.53(\mathrm{~m}, 1 \mathrm{H})$ \\
11 & 20.3 & \\
12 & 31.85 & $1.02-0.95(\mathrm{~m}, 1 \mathrm{H}) 1.74(\mathrm{ddd}, J=22.3,11.2,3.5 \mathrm{~Hz}, 1 \mathrm{H})$ \\
13 & 44.81 & \\
14 & 54.24 & $1.43-1.34(\mathrm{~m}, 1 \mathrm{H}) 1.96-1.92(\mathrm{~m}, 1 \mathrm{H})$ \\
15 & 31.24 & $2.13-2.07(\mathrm{~m}, 1 \mathrm{H}) 2.36-2.30(\mathrm{~m}, 1 \mathrm{H})$ \\
16 & 35.52 & $0.85(\mathrm{~s}, 3 \mathrm{H})$ \\
17 & 218.95 & $1.15(\mathrm{~s}, 3 \mathrm{H})$ \\
18 & 14.16 & \\
19 & 16.7 & \\
\hline
\end{tabular}

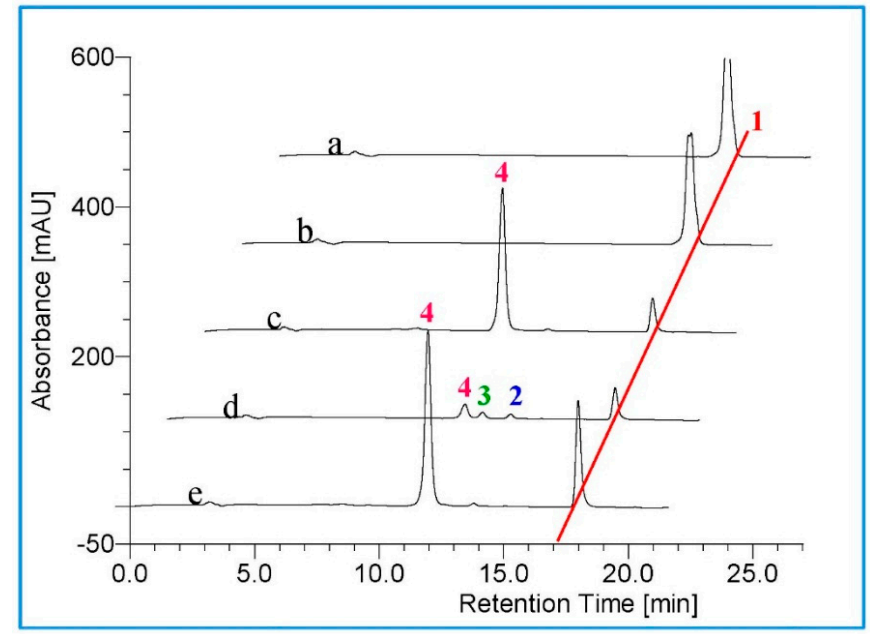

Figure 10. (a) HPLC chromatogram of androstenedione; (b-e) androstenedione incubations with empty vector, M01A82W, M01A82WS72I and M11A82W, respectively. Peak 1 shows the androstenedione standard; peaks 2, 3 and 4 are three monohydroxylated metabolites of androstenedione.

Androstenediol is the $\Delta^{5}-3$-hydroxy configuration of testosterone. Androstenediol was therefore incubated with the three BM3 mutants. As expected, the incubation of androstenediol with the BM3 variants did not result in any new products (Figure S10).

The hydroxylation of steroids is an important enzymatic reaction in the course of preparation of oxysterols and saponins with diverse pharmacological activities. As biocatalysts capable of hydroxylating steroids, bacterial P450 BM3 mutants are considered to have a very broad application prospects. However, the limited substrate diversity mentioned previously hinders their application in the preparation of hydroxylated steroids. In the present investigation, we investigated the oxidation effects of three BM3 mutants on multiple steroid substrates. The P450 BM3 variants chosen for this experiment included M01A82W, M11A82W and M01A82WS72I, which had been shown to display regio- and stereoselective hydroxylation activity towards a few steroid probes [6,7]. From the results, we revealed that these P450 BM3 mutants preferred 3-keto- $\Delta^{4}$-steroids as substrates. To our knowledge, this is the first report about the substrate preference of P450 BM3 variants, which lays a foundation for a structure-activity relationship study of bacterial P450 BM3s.

\section{Experimental Section}

\subsection{Substrates, Chemicals and Enzymes}

Materials used in this study were as follows: a total of 13 steroids were used as substrates in the enzyme assays. The details of the sources of these steroidal substrates are summarized in 
Supplementary Materials Table S1; Restriction enzymes (Takara Shuzo Co. Ltd., Kyoto, Japan) and KOD-Plus-Neo DNA polymerases (Toyobo Co. Ltd., Osaka, Japan) were applied to construct expression vectors; Ni-Sepharose (Invitrogen, Carlsbad, CA, USA) was used for protein purification; Fast Mutagenesis System kit was used for the site-directed mutagenesis of BM3 variants (TransGen Biotech Co. Ltd., Beijing, China). All other chemicals used in this study were of analytical grade.

\subsection{Strains and Plasmids}

Prokaryotic expression vector pET-28a (+), which was used for heterologous expression, was purchased from Novagen (Madison, WI, USA). The CYP102A1 mutants M01A82W (R47L/A82W/ F87V/L188Q/E267V) and M11A82W (R47L/E64G/F81I/A82W/F87V/E143G/L188Q/E267V/ G415S) [7] were synthesized and cloned into expression vector pET-28a (+) by Taihe Biotechnology Co. Ltd. (Beijing, China) One of the resulting expression vector pET28aM01A82W was used either for heterologous expression of M01A82W, or as the template for the third BM3 mutant M01A82WS72I [6]. The E. coli strain Trans1-T1 and Transetta (DE3) (TransGen Co. Ltd., Beijing, China) were used as a bacterial host for recombinant plasmid amplification and enzyme expression, respectively. The strain was grown in Luria-Bertani medium(10 g/L Bacto-Tryptone, $5 \mathrm{~g} / \mathrm{L}$ Bacto-yeast extract, $10 \mathrm{~g} / \mathrm{L} \mathrm{NaCl}$ ) or induced in TB medium (12 g/L Bacto-Tryptone, $24 \mathrm{~g} / \mathrm{L}$ Bacto-yeast extract, $4 \mathrm{~mL}$ glycerol, $72 \mathrm{mM}$ $\left.\mathrm{K}_{2} \mathrm{HPO}_{4}, 17 \mathrm{mM} \mathrm{KH} \mathrm{PO}_{4}\right)$, supplemented with appropriate antibiotics, i.e., kanamycin $(30 \mathrm{mg} / \mathrm{mL})$ and chloromycetin $(34 \mathrm{mg} / \mathrm{mL})$ for selection.

\subsection{Site-Directed Mutagenesis}

Site-directed mutagenesis was performed to obtain the third BM3 mutant M01A82WS72I as described previously [25]. Specifically, the S72I mutation were introduced into M01A82W by PCR-based amplification of the entire pET28aM01A82W expression plasmid using two mutated oligonucleotide primers, each complementary to the opposite strand of the vector. The sequence of the forward primer for the mutation was $5^{\prime}$-TTTGATAAAAACTTAATTCAAGCGCTT- $3^{\prime}$, with the altered residue shown in bold italics. The reverse primer for this position was $5^{\prime}$-ATTAAGTTTTTATCAAAGCGTGATTCA-3'. All components necessary for PCR-based mutagenesis, contained in the Fast Mutagenesis System kit, were used according to the manufacturer's instructions. The mutants were confirmed by sequencing and those plasmids with target substitutions and without other unwanted mutations were retained.

\subsection{Expression and Purification of BM3 Mutants}

The expression plasmids pET28aM01A82W, pET28aM11A82W and pET28aM01A82WS72I were transformed into the expression host strain Transetta (DE3) for heterologous expression of the three BM3 variants. Strains inoculation and genes induction were performed as described previously [25-28]. Briefly, a single transformant containing pET28aM01A82W, pET28aM11A82W or pET28aM01A82WS72I was used to start a $10 \mathrm{~mL} \mathrm{LB}$ culture with chloromycetin $(34 \mathrm{mg} / \mathrm{mL})$ and kanamycin $(30 \mathrm{mg} / \mathrm{mL})$ at $37^{\circ} \mathrm{C}$ and $200 \mathrm{rpm}$. The starter culture was then used to inoculate $100 \mathrm{~mL}$ TB medium for continuous culture until $\mathrm{OD}_{600}$ reached 0.6 at the same antibiotic concentrations as above. Subsequently, isopropyl $\beta$-D-thiogalactopyranoside (IPTG) was added to induce the heterologous expression of M01A82W, M11A82W and M01A82WS72I at the final concentration of $0.1 \mathrm{mM}$. After induction culture at $20^{\circ} \mathrm{C}$ for $20 \mathrm{~h}$, the induced cells were harvested by centrifugation $(10,000 \mathrm{~g}, 5 \mathrm{~min})$ at $4{ }^{\circ} \mathrm{C}$. The resultant cell pellets (derived from $1 \mathrm{~mL}$ culture) were analyzed via SDS-PAGE to confirm the presence of recombinant M01A82W, M11A82W or M01A82WS72I, first and then, the rest cell pellets were prepared for protein purification.

For enzyme purification, all steps were performed at $4{ }^{\circ} \mathrm{C}$. First, E. coli cells were washed and resuspended in lysis buffer (50 $\mathrm{mM}$ potassium phosphate, $\mathrm{pH7.4}$ ). Cells were then lysed with a high-pressure homogenizer (800 bar, 3 passes), after which $1 \mathrm{U} / \mathrm{mL}$ DNaseI was added, and then the homogenate was incubated at $4{ }^{\circ} \mathrm{C}$ for approximately $2 \mathrm{~h}$. After centrifugation at $12,000 \mathrm{~g}$ for $30 \mathrm{~min}$, 
the supernatant was passed through a $0.45 \mu \mathrm{m}$ pore-size filter to remove E. coli cell debris and other contaminants, and then loaded onto a pre-equilibrated $(20 \mathrm{mM}$ sodium phosphate buffer containing $10-50 \mathrm{mM}$ imidazole and $300 \mathrm{mM} \mathrm{NaCl}, \mathrm{pH} 8.0$ ) to remove non-specifically bound proteins, after which an elution buffer $(20 \mathrm{mM}$ sodium phosphate containing $200 \mathrm{mM}$ imidazole and $300 \mathrm{mM} \mathrm{NaCl}$, pH 8.0) was used to elute the His $_{6}$-tagged protein. To remove small molecules such as imidazole, dialysis was performed. A semipermeable membrane with a molecular weight cutoff of $30 \mathrm{kDa}$ was selected and approximately $20 \mathrm{~mL}$ protein sample was dialyzed against $1 \mathrm{~L}$ dialysis buffer $(10 \mathrm{mM}$ sodium phosphate, $\mathrm{pH}$ 8.0) for $4 \mathrm{~h}$ at $4{ }^{\circ} \mathrm{C}$ with four changes of dialysis buffer. Proteins were then either stored at $-80^{\circ} \mathrm{C}$ or used directly.

\subsection{Metabolism of Steroids by CYP102A1 Mutants}

Hydroxylation activity of purified M01A82W, M11A82W or M01A82WS72I was determined by measuring the formation of hydroxylated derivatives from steroid substrates by in vitro reactions. Unless specified otherwise, the final volume of the reaction mixture was $200 \mu \mathrm{L}$, with a steroid substrate concentration of $200 \mu \mathrm{M}$. The reactions were initiated by addition of an NADPH regenerating system (final concentrations of $0.2 \mathrm{mM} \mathrm{NADPH}, 0.3 \mathrm{mM}$ glucose 6-phosphate, and $0.4 \mathrm{unit} / \mathrm{mL}$ glucose-6-phosphate dehydrogenase) using an enzyme-coupled method [29]. The reaction was allowed to proceed for $3 \mathrm{~h}$ at $25^{\circ} \mathrm{C}$ and terminated by the addition of $100 \mu \mathrm{L}$ of chloroform. Precipitated protein was removed by centrifugation $(16,200 \mathrm{~g}, 5 \mathrm{~min})$, and the organic layers were evaporated using a vacuum pump. The formation of hydroxylated steroid derivatives was unambiguously determined by a combination of by HPLC-UV, HPLC-MS, ${ }^{1} \mathrm{H}$ - and ${ }^{13} \mathrm{C}-\mathrm{NMR}$ and LC-SPE-NMR.

HPLC-UV was performed on a LaCrom elite L-2000 HPLC system (Hitachi, Toyokawa, Japan) using a C18 column (YMC-Pack ODS-A $(5 \mu \mathrm{m}, 12 \mathrm{~nm}, 250 \times 4.6 \mathrm{~mm})$ ). Chromatographic condition was as follow. The mobile phase consisted of deionized water-trifluoroacetic acid (A, 99.95\%:0.05\%, $v / v$ ) and acetonitrile (B) in gradient mode as follows: from 1 to $15 \mathrm{~min}$, linear increase from $20 \%$ to $60 \% \mathrm{~B}$; from 15 to $20 \mathrm{~min}$, linear increase to $100 \% \mathrm{~B}$. The flow rate was kept at $1.0 \mathrm{~mL} / \mathrm{min}$ and the column temperature was maintained at ambient. The sample injection volume was $50 \mu \mathrm{L}$. The DAD detection was performed in the range of 210-284 nm. LC-MS and NMR analyses were performed as previously reported $[26,27,30]$. LC-SPE-NMR experiments were performed using an Agilent 1260 series HPLC (Agilent, Palo Alto, CA, USA) interfaced with an AVANCE III HD 600 MHz spectrometer (Bruker, Fallanden, Switzerland). The chromatographic separation was performed using an YMC-Pro C18 column $(5 \mu \mathrm{m}, 12 \mathrm{~nm}, 250 \times 4.6 \mathrm{~mm})$ with an isocratic elution of $65 \%$ water-trifluoroacetic acid (A, $99.95 \%: 0.05 \%, v / v)$ and $35 \%$ acetonitrile (B) at a flow rate of $0.8 \mathrm{~mL} / \mathrm{min}$. The column temperature was maintained at $30{ }^{\circ} \mathrm{C}$. UV spectra were recorded from 190 to $400 \mathrm{~nm}$. Varied hydroxylated metabolites of steroids were enriched using the on-line solid-phase extraction (SPE) add-on. The resulting enriched metabolites were then structurally characterized by NMR analysis at $600 \mathrm{MHz}$ for ${ }^{1} \mathrm{H}-\mathrm{NMR}$ and $150 \mathrm{MHz}$ for ${ }^{13} \mathrm{C}-\mathrm{NMR}$ using the solvent $\mathrm{CDCl}_{3}$. Chemical shifts $(\delta)$ are given in ppm, coupling constants $(J)$ are given in $\operatorname{Hertz}(\mathrm{Hz})$.

\section{Conclusions}

Bacterial P450 BM3 mutants were reported to display altered regio- and stereoselectivities in hydroxylations of a few steroids. P450 BM3 mutants were therefore deemed to be promising candidates for biocatalysis of steroids. Hence, it is necessary to probe the steroidal substrate diversity of these BM3 variants with the aim of obtaining more hydroxylated steroids precursors. In the present investigation, a total of 13 steroids were used as substrates to probe the hydroxylation capacity of three representative BM3 mutants. The results revealed that the three BM3 proteins were indeed able to metabolize 3-keto- $\Delta^{4}$-steroids to monohydroxylated metabolites. On the contrary, the three BM3 mutants had no any oxidative activity on 3 -hydroxy- $\Delta^{5}$-steroids. These results suggest a substrate preference of BM3 mutants towards 3-keto- $\Delta^{4}$-steroids. These results broaden our knowledge of the steroid substrate promiscuity of BM3 variants, thereby expanding their synthetic utility as biological catalysts. 
Supplementary Materials: Supplementary materials can be accessed at: http://www.mdpi.com/1420-3049/21/ 6/760/s1.

Acknowledgments: Financial support by Independent Subject of Key Project of State Key Laboratory of Bioactive Substance and Function of Natural Medicines (GTZA201404) and Institute of Materia Medica Foundation (2016ZD01) is gratefully acknowledged.

Author Contributions: X.Liu performed the experiment. Z.-B.Wang conduced the structural characterization of $16 \beta-O H-M T$. Y.-N.Wang performed LC-NMR analysis of several metabolites. J.-Q.Kong designed the experiment and wrote the manuscript. All authors have given approval to the final version of the manuscript.

Conflicts of Interest: The authors declare no conflict of interest.

\section{References}

1. Mimaki, Y.; Kuroda, M.; Kameyama, A.; Sashida, Y.; Hirano, T.; Oka, K.; Maekawa, R.; Wada, T.; Sugita, K.; Beutler, J.A. Cholestane glycosides with potent cytostatic activities on various tumor cells from Ornithogalum saundersiae bulbs. Bioorg. Med. Chem. Lett. 1997, 7, 633-636. [CrossRef]

2. Kubo, S.; Mimaki, Y.; Terao, M.; Sashida, Y.; Nikaido, T.; Ohmoto, T. Acylated cholestane glycosides from the bulbs of Ornithogalum saundersiae. Phytochemistry 1992, 31, 3969-3973. [CrossRef]

3. Kobayashi, M.; Kanda, F.; Damarla, S.R.; Rao, D.V.; Rao, C.B. Marine sterols. XVII.: Polyhydroxysterols of the soft corals of the andaman and nicobar coasts.: (2). isolation and structures of three $16 \beta$-hydroxy steroidal glycosides from an Alcyonium sp. soft coral. Chem. Pharm. Bull. 1990, 38, 2400-2403. [CrossRef]

4. Goto, G.; Yoshioka, K.; Hiraga, K.; Masuoka, M.; Nakayama, R.; Miki, T. Synthesis and antiandrogenic activity of 16 $\beta$-substituted-17 $\beta$-hydroxysteroids. Chem. Pharm. Bull. 1978, 26, 1718-1728. [CrossRef] [PubMed]

5. Löken, B.; Kaufmann, S.; Rosenkranz, G.; Sondheimer, F. Steroids. LXXVII. 1 Synthesis and reactions of 16ß-oxygenated pregnan-20-one derivatives. J. Am. Chem. Soc. 1956, 78, 1738-1741. [CrossRef]

6. Venkataraman, H.; Beer, S.B.; Bergen, L.A.; Essen, N.; Geerke, D.P.; Vermeulen, N.P.; Commandeur, J.N. A single active site mutation inverts stereoselectivity of 16-hydroxylation of testosterone catalyzed by engineered cytochrome P450 BM3. ChemBioChem 2012, 13, 520-523. [CrossRef] [PubMed]

7. Rea, V.; Kolkman, A.J.; Vottero, E.; Stronks, E.J.; Ampt, K.A.; Honing, M.; Vermeulen, N.P.; Wijmenga, S.S.; Commandeur, J.N. Active site substitution A82W improves the regioselectivity of steroid hydroxylation by cytochrome P450 BM3 mutants as rationalized by spin relaxation nuclear magnetic resonance studies. Biochemistry 2012, 51, 750-760. [CrossRef] [PubMed]

8. Van Vugt-Lussenburg, B.M.; Damsten, M.C.; Maasdijk, D.M.; Vermeulen, N.P.; Commandeur, J.N. Heterotropic and homotropic cooperativity by a drug-metabolising mutant of cytochrome P450 BM3. Biochem. Biophys. Res. Commun. 2006, 346, 810-818. [CrossRef] [PubMed]

9. Pouzar, V.R.; Černý, I.; Lapčík, O.; Hill, M.; Hampl, R. Synthesis of two new haptens of $16 \alpha$-hydroxydehydroepiandrosterone (3ß,16 $\alpha$-dihydroxyandrost-5-en-17-one). Steroids 2003, 68, 149-158. [CrossRef]

10. Denancé, M.; Guyot, M.; Samadi, M. Short synthesis of $16 \beta$-hydroxy-5 $\alpha$-cholestane-3, 6-dione a novel cytotoxic marine oxysterol. Steroids 2006, 71, 599-602. [CrossRef] [PubMed]

11. Venkataraman, H.; Te Poele, E.M.; Rosloniec, K.Z.; Vermeulen, N.; Commandeur, J.N.; van der Geize, R.; Dijkhuizen, L. Biosynthesis of a steroid metabolite by an engineered Rhodococcus erythropolis strain expressing a mutant cytochrome P450 BM3 enzyme. Appl. Microbiol. Biotechnol. 2015, 99, 4713-4721. [CrossRef] [PubMed]

12. Wong, L.-L. P450BM3 on steroids: the swiss army knife p450 enzyme just gets better. ChemBioChem 2011, 12, 2537-2539. [CrossRef] [PubMed]

13. Warman, A.J.; Roitel, O.; Neeli, R.; Girvan, H.M.; Seward, H.E.; Murray, S.A.; McLean, K.J.; Joyce, M.G.; Toogood, H.; Holt, R.A.; et al. Flavocytochrome P450 BM3: An update on structure and mechanism of a biotechnologically important enzyme. Biochem. Soc. Trans. 2005, 33, 747-753. [CrossRef] [PubMed]

14. Narhi, L.O.; Fulco, A.J. Characterization of a catalytically self-sufficient 119,000-dalton cytochrome P-450 monooxygenase induced by barbiturates in Bacillus megaterium. J. Biol. Chem. 1986, 261, 7160-7169. [PubMed]

15. Glieder, A.; Farinas, E.T.; Arnold, F.H. Laboratory evolution of a soluble, self-sufficient, highly active alkane hydroxylase. Nat. Biotechnol. 2002, 20, 1135-1139. [CrossRef] [PubMed] 
16. Carmichael, A.B.; Wong, L.-L. Protein engineering of Bacillus megaterium CYP102. Eur. J. Biochem. 2001, 268, 3117-3125. [CrossRef] [PubMed]

17. Li, Q.S.; Schwaneberg, U.; Fischer, P.; Schmid, R.D. Directed evolution of the fatty-acid hydroxylase P450 BM-3 into an indole-hydroxylating catalyst. Chem. A Eur. J. 2000, 6, 1531-1536. [CrossRef]

18. Vottero, E.; Rea, V.; Lastdrager, J.; Honing, M.; Vermeulen, N.P.E.; Commandeur, J.N.M. Role of residue 87 in substrate selectivity and regioselectivity of drug-metabolizing cytochrome P450 CYP102A1 M11. J. Biol. Inorg. Chem. 2011, 16, 899-912. [CrossRef] [PubMed]

19. Reinen, J.; Vredenburg, G.; Klaering, K.; Vermeulen, N.P.E.; Commandeur, J.N.M.; Honing, M.; Vos, J.C. Selective whole-cell biosynthesis of the designer drug metabolites 15- or 16-betahydroxynorethisterone by engineered Cytochrome P450 BM3 mutants. J. Mol. Catal. B Enzym. 2015, 121, 64-74. [CrossRef]

20. Kille, S.; Zilly, F.E.; Acevedo, J.P.; Reetz, M.T. Regio- and stereoselectivity of P450-catalysed hydroxylation of steroids controlled by laboratory evolution. Nat. Chem. 2011, 3, 738-743. [CrossRef] [PubMed]

21. Di Bari, L.; Pescitelli, G.; Pratelli, C.; Pini, D.; Salvadori, P. Determination of absolute configuration of acyclic 1,2-diols with $\mathrm{Mo}_{2}(\mathrm{OAc})_{4}$. 1. Snatzke's method revisited. J. Org. Chem. 2001, 66, 4819-4825. [PubMed]

22. Górecki, M.; Jablonska, E.; Kruszewska, A.; Suszczynska, A.; Urbanczyk-Lipkowska, Z.; Gerards, M.; Morzycki, J.W.; Szczepek, W.J.; Frelek, J. Practical method for the absolute configuration assignment of tert/tert 1,2-diols using their complexes with $\mathrm{Mo}_{2}$ (OAc) 4 . J. Org. Chem. 2007, 72, 2906-2916. [CrossRef] [PubMed]

23. Musharraf, S.G.; Ali, A.; Khan, N.T.; Yousuf, M.; Choudhary, M.I. Tandem mass spectrometry approach for the investigation of the steroidal metabolism: Structure-fragmentation relationship (SFR) in anabolic steroids and their metabolites by ESI-MS/MS analysis. Steroids 2013, 78, 171-181. [CrossRef] [PubMed]

24. Agematu, H.; Matsumoto, N.; Fujii, Y.; Kabumoto, H.; Doi, S.; Machida, K.; Ishikawa, J.; Arisawa, A. Hydroxylation of testosterone by bacterial cytochromes P450 using the Escherichia coli expression system. Biosci. Biotechnol. Biochem. 2006, 70, 307-311. [CrossRef] [PubMed]

25. Wang, Z.-B.; Chen, X.; Wang, W.; Cheng, K.-D.; Kong, J.-Q. Transcriptome-wide identification and characterization of Ornithogalum saundersiae phenylalanine ammonia lyase gene family. RSC Adv. 2014, 4, 27159-27175. [CrossRef]

26. Li, L.-N.; Kong, J.Q. Transcriptome-wide identification of sucrose synthase genes in Ornithogalum caudatum. RSC Adv. 2016, 6, 18778-18792. [CrossRef]

27. Guo, L.; Chen, X.; Li, L.-N.; Tang, W.; Pan, Y.-T.; Kong, J.-Q. Transcriptome-enabled discovery and functional characterization of enzymes related to (2S)-pinocembrin biosynthesis from Ornithogalum caudatum and their application for metabolic engineering. Microb. Cell Fact. 2016, 15, 27. [CrossRef] [PubMed]

28. Guo, L.; Kong, J.-Q. cDNA cloning and expression analysis of farnesyl pyrophosphate synthase from Ornithogalum saundersiae. Z. Naturforsch. C 2014, 69, 259-270. [CrossRef] [PubMed]

29. Pongtharangkul, T.; Chuekitkumchorn, P.; Suwanampa, N.; Payongsri, P.; Honda, K.; Panbangred, W. Kinetic properties and stability of glucose dehydrogenase from Bacillus amyloliquefaciens SB5 and its potential for cofactor regeneration. AMB Express 2015, 5, 68. [CrossRef] [PubMed]

30. Yin, S.; Kong, J.-Q. Transcriptome-guided discovery and functional characterization of two UDP-sugar 4-epimerase families involved in the biosynthesis of anti-tumor polysaccharides in Ornithogalum caudatum. RSC Adv. 2016, 6, 37370-37384. [CrossRef]

Sample Availability: Samples of the compounds $2 \beta-, 16 \alpha-$ and $16 \beta-\mathrm{OH}-\mathrm{T}, 2 \beta-, 16 \alpha-$ and $16 \beta-\mathrm{OH}-\mathrm{MT}$ and $1 \alpha-\mathrm{OH}$-androstenedione are available from the authors.

(C) 2016 by the authors; licensee MDPI, Basel, Switzerland. This article is an open access article distributed under the terms and conditions of the Creative Commons Attribution (CC-BY) license (http://creativecommons.org/licenses/by/4.0/). 